\title{
Glycemic Control in Diabetes Type 2 Patients in Foster Families of Brod-Posavina County During the COVID-19 Pandemic
}

\author{
Blaženka Miškić*1,3, Vesna Ćosić*1,3, Karla Miškić1, Ines Rajkovača Latićí,2,3, Domagoj Vučić ${ }^{3}$, Blaženka Kljaić \\ Bukvićc $^{1,3}$, Dario Rahelić ${ }^{4}$, Marijana Knezević Praveček ${ }^{1,3}$ \\ *equally contributed \\ ${ }^{1}$ Faculty of Dental Medicine and Health, University of Josip Juraj Strossmayer Osijek, Croatia \\ ${ }^{2}$ Faculty of Medicine Osijek, University of Josip Juraj Strossmayer University of Osijek, Osijek, Croatia \\ ${ }^{3}$ General Hospital "Dr. Josip Benčević”, Slavonski Brod, Croatia \\ ${ }^{4}$ Vuk Vrhovac University Clinic for Diabetes, Zagreb, Croatia
}

\begin{abstract}
A B S T R A C T
COVID-19 pandemic has changed everyday life and medical supervision of chronically ill patients. Epidemiological measures, social distancing, and limited access to medical care impair glycemic control in patients with diabetes. Also, type 2 diabetes is a risk factor for more severe form of coronavirus disease. A large proportion of diabetic patients are placed in foster families who also adapt to the new situation. The purpose of this study was to examine the manner and frequency of glycemic control in patients with type 2 diabetes who are placed in foster families in the region of BrodPosavina County. We established contact with patients suffering from type 2 diabetes situated in foster families and their caregivers. Measurement of glycemia was performed several times a day with regular notes and the data were supplemented by an insight into the medical documentation of patients in the hospital information system. The study included 33 patients with type 2 diabetes. The relationship between $H b A 1 C$ with fasting and postprandial glycemia was linear. There were no statistically significant differences in HbA1C regulation by type of therapy. There was a significant difference in the number of complications according to the level of HbA1C (Hi square test $=25.982, p<.001)$. The number of complications generally increased as HbA1C regulation was poorer. During current COVID-19 pandemic, care for patients with type 2 diabetes is significantly limited. Improved medical care for patients can be achieved by establishing cooperation and daily communication between caregivers, family physicians and, if necessary, diabetologists, especially through the use of online platforms and telephone communication, all with the aim of early detection of diabetes complications and adequate treatment of patients in current conditions.
\end{abstract}

Key words: COVID-19, diabetes mellitus, glycemic control, foster families

\section{Introduction}

The COVID-19 pandemic, due to high infection rate of SARS-CoV-2 and the possibility of severe and even fatal complications, significantly changed our lives, limited many activities, temporarily delayed the treatment of non-communicable diseases, disrupted communication with health care and increased the number of chronic complications in the long run ${ }^{1-2}$. Middle-aged and elderly people are at high risk because of the associated comorbidities $^{3}$.

Although diabetes does not increase the risk of SARSCoV-2 infection, some studies show that diabetes is the second most common comorbidity in COVID-193-4 . Diabetics have a high risk of poor outcomes due to associated complications with the onset of COVID-19, while numerous studies show that better regulation of glycemia improves outcomes in the presence of SARS-CoV-2 infection ${ }^{4}$. Well-controlled glycemia is positively correlated with a reduction in the relative risk of all causes of death as well as the consequences of SARS-CoV-2 infection ${ }^{5}$.

In addition to general instructions on preventing the spread of SARS-CoV-2 infection, special recommendations have been issued for diabetics, which include adequate

Received for publication April 26, 2021 
nutrition, physical activity as possible, more frequent glycemic control and consultation with general practitioners if necessary. The burden of the health system with the current pandemic has reduced the scheduled visits of patients with chronic non-communicable diseases, especially hypertension, obesity, depression, and alcoholism ${ }^{6}$.

In the Republic of Croatia during the quarantine in April/May 2020, the care for diabetic patients in personal contact was only during visits to emergency department for glycemic disorders. Redistribution of medical staff and epidemiological recommendations interrupted function of outpatient's clinics and diabetes education center. Newly diagnosed patients with diabetes as well as chronic patients have the possibility of direct individual education on lifestyle changes, activities and application of adequate therapy as well as on methods of self-care in conditions of hypoglycemia or hyperglycemia. The only possibility of complete diabetes education was carried out only through acute hospitalizations. Additional treatments for possible complications as well as their prevention were currently stopped.

Diabetes consultations took place by telephone or on a personal level in agreement with the family doctor, until electronic consultations between general practitioner and diabetologists were introduced. Care for diabetics situated in state homes for the elderly also took place by telephone collaboration with health staff.

In the first months of the epidemic, diabetologists control and regulation of glycemia among diabetics placed in foster families was not carried out by scheduled visits. Patients from such systems were only hospitalized with severe metabolic disorders through emergency admissions. Precisely because of the difficulties in system like this, we were interested in the care for diabetic patients in foster families. The aim of the study was to establish the method of glucoregulation of diabetics in foster families during the COVID 19 pandemic.

\section{Participants and methods}

In Brod-Posavina County, in cooperation with the Centre for social work, we established contacts with foster care and made a cross-sectional survey of the current situation during May 2020. We gained insight into the number of foster care, the age and educational structure of foster stuff and the status of diabetics they care for. From patient's medical records, we determined overall health status, diabetes complications, date of the last scheduled visit and the last recommended therapy. We observed the age and sex distribution of subjects, fasting glycemia and 2 hours after meals values, the degree of glycemic regulation assessed by glycated haemoglobin level and current therapy. The correlation of therapy with regulation and the presence of associated complications with the medications that patients are taking were also analyzed. Average values of glycated haemoglobin as a measure of regulation are individualized and adjusted according to the latest recommendations for the elderly population from Diabetes Care 2020.

We compared the data by telephone contact and approached the individual treatment of patients. Foster owners sent us data of the anthropometric characteristics of patients via the Viber or What's App application. They informed us about fasting glycemia and postprandial glycemia. Once a week, they sent us the daily profiles of the glycemia as well as the type and dose of therapy they were receiving. In cases of individual deviations, controls were performed more frequently.

\section{Statistical methods}

The data are described by descriptive statistics: calculation of percentages for categorical variables and average values and scattering measures for continuous variables. The degree of correlation between continuous variables was estimated by the Pearson correlation coefficient. The significance of the differences between the categorical variables was assessed using the Chi square test. The significance level used was 5\%. Processing were carried out in the SPSS 24 program

\section{Results}

During the epidemic, 108 patients were placed in foster families in Brod-Posavina county, of whom 33 had type 2 diabetes. There were no patients with type 1 diabetes. Descriptive data of respondents are shown in Table 1. (Table 1, Figure 1)

As shown in Figure 1, the relationship between HbA1C with fasting and postprandial glycaemia was linear. The higher the $\mathrm{HbA} 1 \mathrm{C}$ value, the higher the GP fasting value, and this correlation was large in strength $(\mathrm{r}=0.82, \mathrm{p}$ $<.001$ ). Also, the higher the value of $\mathrm{HbA1C}$, the higher the value of GP postprandial, and this correlation was also large in strength $(\mathrm{r}=0.81, \mathrm{p}<.001)$.

There were no statistically significant differences in $\mathrm{HbA1C}$ regulation by type of therapy (Tables $3-5$, Figures 2 and 3).

A significant difference in the number of complications existed only when using Premix and in the direction that patients using Premix had more complications Premix was prescribed to patients with a more severe picture (Table 5). (Figures 4 and 5)

There was a significant difference in the number of complications according to the level of HbA1C (Hi square test $=25.982, p<.001)$. The number of complications generally increased as HbA1C regulation was poorer (Table 6, Figure 6).

\section{Discussion and conclusion}

Despite well known risk factors and complications of diabetes, adequate education, good glycemic control, and clinical inertia are major factors in improving the negative 
TABLE 1

DESCRIPTIVE DATA OF RESPODENTS

\begin{tabular}{lcccccc}
\hline & $\mathrm{n}$ & $\%$ & Min & Max & M & SD \\
\hline Age & 32 & & 62.00 & 88.00 & 74.4 & 6.0 \\
Sex & & & & & & \\
Male & 13 & $40.6 \%$ & & & & \\
Female & 19 & $59.4 \%$ & & & & \\
BMI(body mass index) & 32 & & 25.4 & 37.2 & 30.5 & 3.5 \\
${ }^{* H b A 1 C}$ & 32 & & 6.00 & 11.2 & 8.2 & 1.4 \\
${ }^{*}$ HbA1C categories & & & & & & \\
Good regulation 6,5-7,5\% & 12 & $37.5 \%$ & & & & \\
Middle regulation 7,6-8,0\% & 4 & $12.5 \%$ & & & & \\
Low regulation 8,1-9,0\% & 9 & $28.1 \%$ & & & & \\
Very low regulation >9\% & 7 & $21.9 \%$ & & & & \\
GP NT( fasting glycemia) & & & 6.7 & 15.2 & 9.5 & 2.2 \\
GP PP (postprandial glycemia) & & & 7.1 & 16.3 & 10.7 & 2.7 \\
\hline
\end{tabular}

*Orientation ranges of $\mathrm{HbA1c}$ (otherwise determined individually depending on age, disease duration, and associated complications), this is a personal clinical distribution dependent on the observed population.
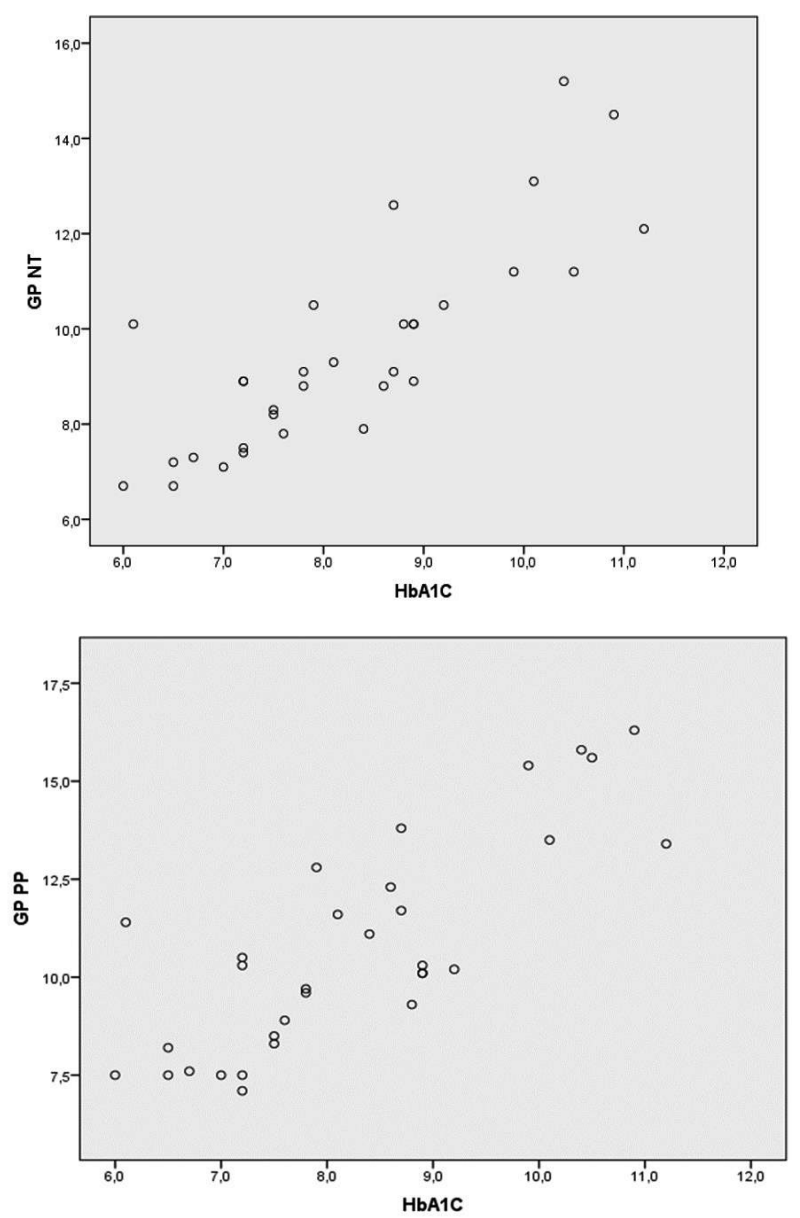

Fig. 1. Relationship of HBA1C with glucose profile on an empty stomach and after meals.
TABLE 2

NUMBER OF PATIENTS RECEIVING A PARTICULAR THERAPY

\begin{tabular}{lcc}
\hline *Therapy & $\mathrm{n}$ & $(\%)$ \\
\hline SU & 4 & $12.5 \%$ \\
DDP4 IH & 9 & $28.1 \%$ \\
SGLT2 IH & 20 & $62.5 \%$ \\
MET & 28 & $87.5 \%$ \\
MET_categories & 4 & $12.5 \%$ \\
0 & & \\
850 & 2 & $6.3 \%$ \\
1500 & 3 & $9.4 \%$ \\
1700 & 10 & $31.3 \%$ \\
2000 & 13 & $40.6 \%$ \\
GLP1 AR & 6 & $18.8 \%$ \\
Premix & 6 & $18.8 \%$ \\
Total number of medications & & \\
1 & 3 & $9.4 \%$ \\
2 & 17 & $53.1 \%$ \\
3 & 12 & $37.5 \%$ \\
\hline
\end{tabular}

*SU(sulphonyurea's derivats); DDP4-IH (dipeptidil peptidase 4 inhibitors); SGLT2-IH (Sodium glucose transport 2 inhibitors); MET(metformin ); GLP1-AR (glucagon like peptids1 agonist receptor); Premix (premix insulin analogs) 
TABLE 3

HBA1C ACCORDING TO THE TYPE OF DRUG ADMINISTERED

\begin{tabular}{|c|c|c|c|c|c|c|c|c|c|}
\hline & \multicolumn{2}{|c|}{ Good regulation } & \multicolumn{2}{|c|}{ Middle regulation } & \multicolumn{2}{|c|}{ Low regulation } & \multicolumn{2}{|c|}{ Very low regulation } & \multirow[t]{2}{*}{ Hi square test (p) } \\
\hline & $\mathrm{n}$ & $(\%)$ & $\mathrm{n}$ & $(\%)$ & $\mathrm{n}$ & $(\%)$ & $\mathrm{n}$ & $(\%)$ & \\
\hline $\mathrm{SU}$ & 1 & $25.0 \%$ & 0 & 0 & 1 & $25.0 \%$ & 2 & $50.0 \%$ & $2.431(.49)$ \\
\hline DDP4 & 6 & $66.7 \%$ & 1 & $11.1 \%$ & 1 & $11.1 \%$ & 1 & $11.1 \%$ & $4.812(.19)$ \\
\hline SGLT & 8 & $40.0 \%$ & 3 & $15.0 \%$ & 6 & $30.0 \%$ & 3 & $15.0 \%$ & $1.575(.67)$ \\
\hline MET & 11 & $39.3 \%$ & 3 & $10.7 \%$ & 7 & $25.0 \%$ & 7 & $25.0 \%$ & $2.54(.47)$ \\
\hline GLP1 AR & 3 & $50.0 \%$ & 1 & $16.7 \%$ & 1 & $16.7 \%$ & 1 & $16.7 \%$ & $0.847(.84)$ \\
\hline Premix & 0 & 0 & 1 & $16.7 \%$ & 2 & $33.3 \%$ & 3 & $50.0 \%$ & $5.613(.13)$ \\
\hline \multicolumn{10}{|c|}{ Number of medications } \\
\hline 1 & 1 & $33.3 \%$ & 0 & 0 & 2 & $66.7 \%$ & 0 & 0 & $2.431(.49)$ \\
\hline 2 & 5 & $29.4 \%$ & 3 & $17.6 \%$ & 5 & $29.4 \%$ & 4 & $23.5 \%$ & \\
\hline 3 & 6 & $50 \%$ & 1 & $8.3 \%$ & 2 & $16.7 \%$ & 3 & $25.0 \%$ & \\
\hline
\end{tabular}

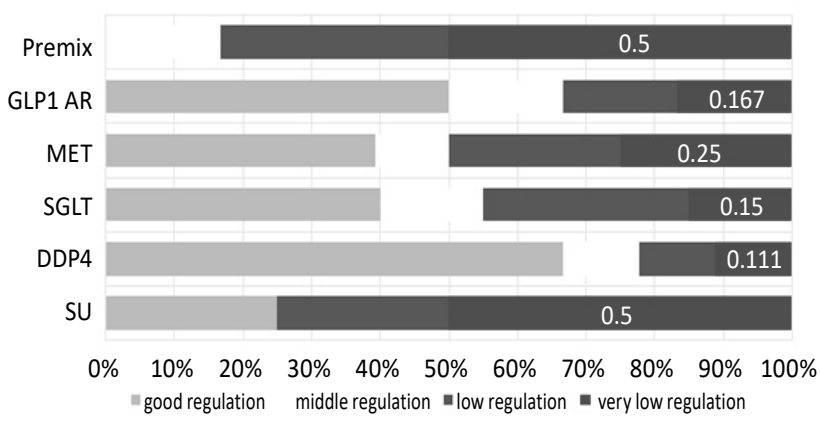

Fig. 2. HBA1C values according to the type of drug the patient is receiving.

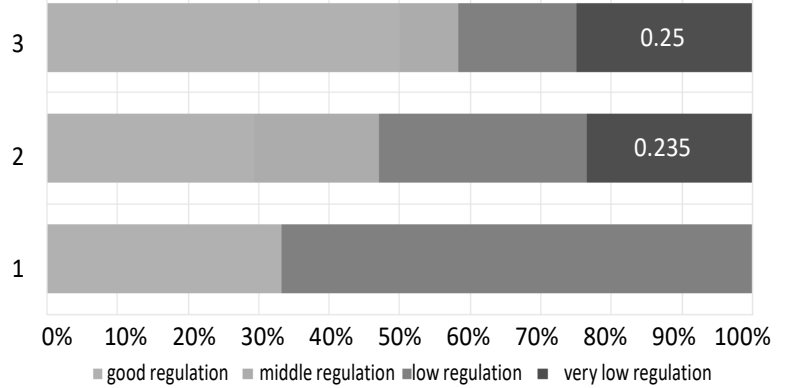

Fig 3. HbA1c values according to the number of drugs patient is receiving.
TABLE 4

DIABETIC COMPLICATIONS

\begin{tabular}{lcc}
\hline$*$ & $\mathrm{n}$ & $(\%)$ \\
\hline CHD & 21 & $65.6 \%$ \\
AKS & 11 & $34.4 \%$ \\
CVD & 19 & $59.4 \%$ \\
CKD & 9 & $28.1 \%$ \\
HA & 31 & $96.9 \%$ \\
HLP & 32 & $100.0 \%$ \\
PAD & 5 & $15.6 \%$ \\
DR & 4 & $12.5 \%$
\end{tabular}

Number of complications

$\begin{array}{lcc}2-3 & 11 & 34.4 \% \\ 4-5 & 15 & 46.9 \% \\ 6-7 & 6 & 18.8 \%\end{array}$

${ }^{*} \mathrm{CHD}$ ( chronical heart disease); AKS (acute coronary sindrom); CVD (cardivascular disease); CKD ( chronical kidney disease); HA (arterial hypertension; HLP (hyperlipoprtoteinemy); PAD (peripheral artery disese), DR (Diabetic rethinopaty)
TABLE 5

NUMBER OF COMPLICATIONS ACCORDING TO THE TYPE OF THE THERAPY

\begin{tabular}{lccccccc}
\hline & \multicolumn{2}{c}{$2-3$} & \multicolumn{2}{c}{$4-5$} & \multicolumn{2}{c}{$6-7$} & Hi square $(\mathrm{p})$ \\
\cline { 2 - 8 } & $\mathrm{n}$ & $(\%)$ & $\mathrm{n}$ & $(\%)$ & $\mathrm{n}$ & $(\%)$ & \\
\hline SU & 2 & $50,0 \%$ & 2 & $50,0 \%$ & 0 & $0 \%$ & $1.191(.55)$ \\
DDP4 & 3 & $33,3 \%$ & 6 & $66,7 \%$ & 0 & $0 \%$ & $3.398(.18)$ \\
SGLT & 8 & $40,0 \%$ & 10 & $50,0 \%$ & 2 & $10,0 \%$ & $2.78(.25)$ \\
MET & 11 & $39,3 \%$ & 12 & $42,9 \%$ & 5 & $17,9 \%$ & $2.44(.30)$ \\
GLP1 AR & 0 & $0 \%$ & 4 & $66,7 \%$ & 2 & $33,3 \%$ & $3.993(.14)$ \\
Premix & 0 & $0 \%$ & 2 & $33,3 \%$ & 4 & $66,7 \%$ & $11.87(.003)$ \\
Number of medications & & & & & & \\
1 & 0 & $0 \%$ & 2 & $66,7 \%$ & 1 & $33,3 \%$ & $6.569(.16)$ \\
2 & 9 & $52,9 \%$ & 5 & $29,4 \%$ & 3 & $17,6 \%$ & \\
3 & 2 & $16,7 \%$ & 8 & $66,7 \%$ & 2 & $16,7 \%$ & \\
\hline
\end{tabular}




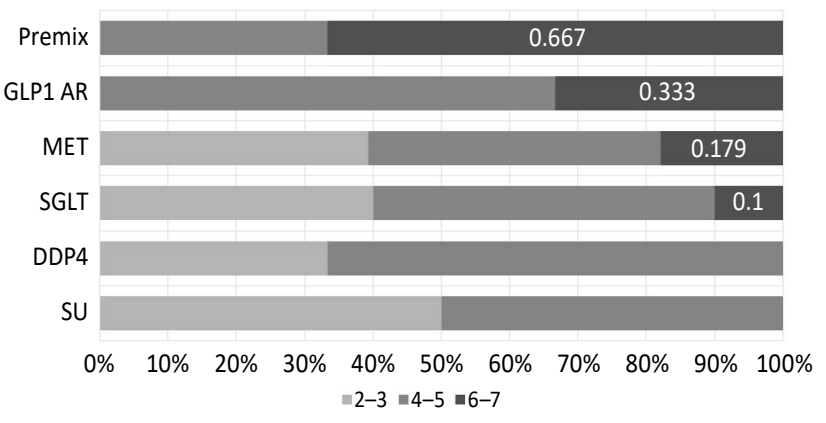

Fig 4. Number of complications according to the therapy.

TABLE 6

NUMBER OF COMPLICATIONS ACCORDING TO HBA1C

\begin{tabular}{lcccccc}
\hline & \multicolumn{2}{c}{$2-3$} & \multicolumn{2}{c}{$4-5$} & \multicolumn{2}{c}{$6-7$} \\
\cline { 2 - 7 } & $\mathrm{n}$ & $(\%)$ & $\mathrm{n}$ & $(\%)$ & $\mathrm{n}$ & $(\%)$ \\
\hline HbA1C & & & & & & \\
Good regulation & 5 & $41,7 \%$ & 6 & $50,0 \%$ & 1 & $8,3 \%$ \\
Middle regulation & 1 & $25,0 \%$ & 3 & $75,0 \%$ & 0 & $0 \%$ \\
Low regulation & 2 & $22,2 \%$ & 6 & $66,7 \%$ & 1 & $11,1 \%$ \\
Very low regulation & 3 & $42,9 \%$ & 0 & $0 \%$ & 4 & $57,1 \%$ \\
\hline
\end{tabular}

outcomes of diabetes treatment. The introduction of new drugs with proven cardiovascular protection, the change of the Guidelines for the treatment of diabetes allows the reduction of major adverse cardiovascular events (MACE) 3,4 and other high-risk conditions. Easy administration of new drugs with flexible regimens improves adherence and provides longer therapy, which is seen in the clinical outcomes. Implementation of new drugs is difficult, even in the highly developed countries with well-organized health systems and the results are still below expectations.

Deviation of everyday life, especially during the outbreak of the COVID 19 pandemic significantly complicates the care for diabetic patients. The burden on the health system, the less possibility of contacts with members of the diabetic team, less mobility of the population, and local isolation significantly worsen the implementation of adequate control and care for diabetics. Implementation of self-control measures and telephone counselling of dietary regimes with limited physical activity are necessary measures to maintain a seemingly normal control in the newly created conditions. Overcrowding in family medicine limits the possibilities of changing, and adjusting differential therapy, which overall contributes to poor patient regulation during COVID-19 infection.

Regimes of glycemic control and regulation in nursing homes and foster families are, even in normal circumstances, unfortunately significantly different from everyday care. Achievements in glycemic care and control are
3

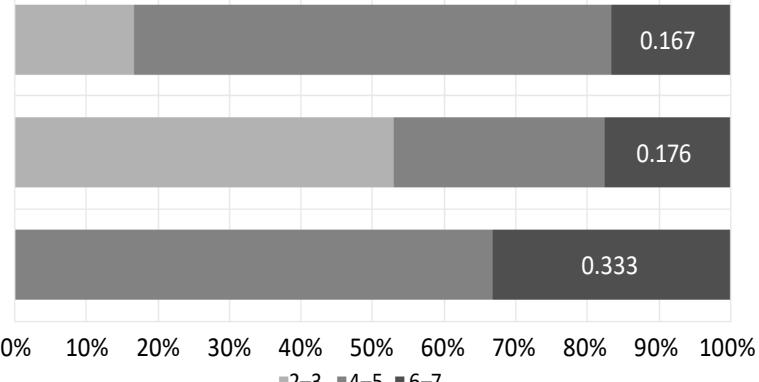

$2-3=4-5=6-7$

Fig 5. Number of complications according to the therapy.

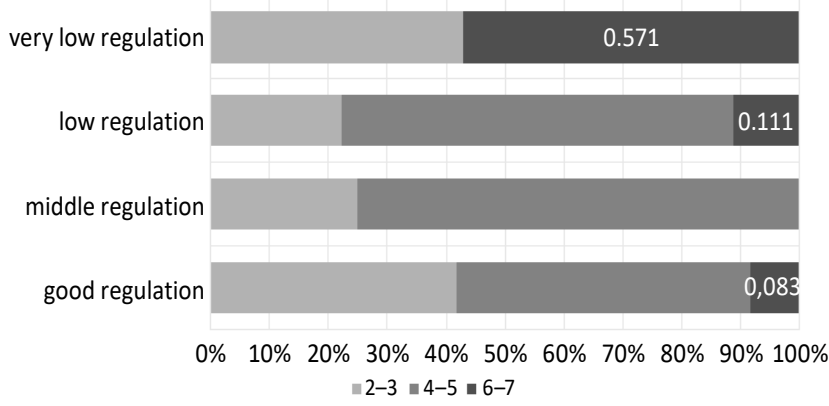

Fig 6. Number of complications according to HBA1C.

the result of a personal engagement of individual, rather than an organized system. According to the law of the Republic of Croatia, eligibility criteria for family-based foster care are adult unpunished persons, legally prescribed accommodation condition for placed 4-8 persons. Persons which provide family-based foster care, aren't obligatory to have any medical education. Neither do, there is no recommendations by national diabetic societies about the basic medical education of foster caregivers. Current circumstances of quarantine and limited availability of health care system, increases the awareness of necessity of diabetes education for all members of family-based foster care.

The care and screening of the elderly with diabetes have to be more frequent and individually regulated, because of the many comorbidities and higher risk for complications ${ }^{2,4,6}$. Person with diabetes in foster family, have little or no motive for self-management and self-control of glycaemia. Faced with the problem of glycemic control and regulation during a pandemic, we tested and organized new methods of caring for diabetics in foster families. According to the hospital medical documentation and foster care, one third (34.5\%) of the diabetic wards were not on diabetic control for the past 30 months.

Glycemic controls were performed by family members until they came to foster care, and then depending about the initiative, education, and age of the foster care owner. About $25 \%$ of fosters are middle-aged, of secondary edu- 
cational status and occasionally performed glycemic checks once a week. $30 \%$ of fosters contacted family physicians for the issuance of glycemic reading strips. Only $5 \%$ of wards from foster families underwent screening for complications, but according to the medical record, most of them had complications before the coming to foster care. Our cross-sectional survey of foster care during May 2020 showed that 50\% participants, respectively to their age, were poorly regulated.

Patients were treated in accordance with current guidelines of the American Diabetes Association, European Association for the Study of Diabetes, and the Croatian Diabetes Society. Subjects which used mixed insulin analogues, in accordance with previous trends in diabetes treatment, had more complications. One of the goals of introduction of premixed insulin analogues was to improve glucoregulation and reduce complications. But, premixed insulin analogues failed to protect study participants from complications. Combinations of individual drugs among study participants, were associated with less complications, what was in concordance with previous publish studies. A negative correlation between fasting and postprandial glycaemia was also confirmed, referred on inappropriate carbohydrate intake and necessity of diabetic diet education. A huge proportion of participants had poor glycemic control, which is partly a consequence of general practitioner's unavailability and foster ignorance. So, we proposed the one way of problem solution through the online education.

Screening for diabetes complications in older adults should be individualized and periodically revisited, as the results of screening tests may impact targets and therapeutic approaches ${ }^{2-4}$.

Studies on the use of technological advances in education of self-control and support of diabetics showed that during 2017 and 2018 mobile phones were most often used to send reports on glycaemia, doses, treatment regimens and degree of regulation, while telephone messages and electronic communication were somewhat less represented. Recently, the introduction of telemedicine in educational and observational procedures in the treatment of diabetics is taking over most of the control and care of patients ${ }^{7}$.

The benefit of telemedicine, were observed in the COVID-19 pandemic, through reduced live direct communication, enables personal contact with the patient, insight into the results of measurement and monitoring of the patient based on all present data, and adjustment and change of therapy. At the same time, it represents a significant opportunity to educate and increase knowledge about one's own illness, treatment and control ${ }^{8-11}$.

Despite the known possibilities of improving technologies in the monitoring and care of patients with diabetes, most of the technological advances are gradually coming into practice and currently benefit the younger generations the most. It is to be expected that institutionalized systems have somewhat less difficulty in estab- lishing virtual telemedicine consultation. Guided by the recommendations of the National committee for the treatment and prevention of diabetes, there is still difficulties in implementing glycemic control in state homes for the elderly and, family homes and especially in foster families. Caregivers do not have properly medical education for care and control of patients with chronic diseases. At the end of the research, specialist diabetes team held an online meeting with foster care owners. One of conclusion was an organization of three-day training module which included: nutrition, exercise, foot care, glycemic control and the application of adequate therapy. Educational material in the form of Power point presentations and leaflets were prepared and sent to the foster families by e-mail. Also, it was agreed to report glycemic levels online on a weekly basis for all wards with the possibility of individualization as needed. Some patients, with the support of their families, got the Libre on-line glycemic control system, which improved the level of control. Foster carers themselves are considering the possibility of implementing a Libre on-line glycemic control system, as a part of care for their diabetic wards. We expect that this cooperation will ensure better care for patients and reduce long-term complications.

\section{Conclusion}

The optimal glycemic control and good regulation of diabetics in foster families is demanding but solvable. Foster carers as individuals or families are not trained to apply all the recommended measures to improve and maintain quality care for diabetics. Medical education on management diabetes will enable foster family to implement basic measures of control and regulation of glycaemia. Online reporting and possible daily telephone communication with diabetologists and family physicians will certainly improve the care for people in foster care. The economic effects will be seen later.

\section{Ethics statement}

This research was approved by General hospital „Dr. Josip Bencevic“, Slavonski Brod Ethics committee with 04000000/20-2 number of approval. All participants signed informed consent. The guidelines outlined in the Declaration of Helsinki were followed.

\section{Conflict of Interest Statement}

The authors declare that the research was conducted in the absence of any commercial or financial relationships that could be construed as a potential conflict of interest.

\section{Funding}

This work was not supported by any funding source. 


\section{Acknowledgments}

The authors would like to thank the caregivers who helped gather valuable data without which this study would not exist.

\section{R E F E R E N C E S}

1. WU Z, McGOOGAN JM, JAMA, 323/13 (2020) 1239. doi:10.1001/jama.2020.2648. - 2. GUAN WJ, NI ZY, HU Y, LIANG WH, OU CQ, HE JX, LIU L, SHAN H, LEI CL, HUI DSC, DU B, LI LJ, ZENG G,YUEN KY, CHEN RC, TANG CL,WANG T, CHEN PY, XIANG J, LI SY, WANG JL, LIANG ZJ, PENG YX, WEI L, LIU Y, HU YH, PENG P, WANG JM, LIU JY, CHEN Z, LI G, ZHENG ZJ, QIU SQ, LUO J, YE CJ, ZHU SY, ZHONG NS, N Engl J Med, 382/18 (2020) 1708. doi: 10.1056/NEJMoa2002032. - 3. WANG W, XU Y, GAO R, LU R, HAN K, WU G, TAN W, JAMA, 323/18 (2020) 1843. doi: 10.1001/jama.2020.3786. — 4.ZU ZY, JIANG MD, XU PP, CHEN W, NI QQ, LU GM, ZHANG LJ, Radiology, 296/2 (2020) E15. doi: 10.1148/radiol.2020200490. - 5. ZHU L, SHE ZG, CHENG X, QIN JJ, ZHANG XJ, CAI J, LEI F, WANG H, XIE J, WANG W, LI H, ZHANG P, SONG X, CHEN X, XIANG M, ZHANG C, BAI L, XIANG D, CHEN MM, LIU Y, YAN Y, LIU M, MAO W, ZOU J, LIU L, CHEN G, LUO P, XIAO B, ZHANG C, ZHANG Z, LU Z, WANG J, LU H, XIA X, WANG D, LIAO X, PENG G,
YE P, YANG J, YUAN Y, HUANG X, GUO J, ZHANG BH, LI H, Cell Metab, 31/6 (2020) 1068e3. doi:10.1016/j. cmet.2020.04.021. - 6. BODE B, GARRETT V, MESSLER J, MCFARLAND R, CROWE J, BOOTH R, KLONOFF DC, .J Diabetes Sci Technol, 14/4 (2020) 813. doi: 10.1177/1932296820924469. - 7. KITSIOU S, PARE G, JAANA M, GERBER B, PLoS One, 12/3 (2017) e0173160. doi:10.1371/journal.pone.0173160. - 8. SHEN Y, WANG F, ZHANG X, ZHU X, SUN Q, FISHER E, SUN X, J Med Internet Res, 20/5 (2018) e172. doi: 10.2196/ jmir.9133. - 9. PENG X, CHEN Y, DENG L, LIU Q, LI Q, XIONG J, SHI Y, TANG S, .Int J Diabetes Dev Ctries, Epub ahead of print (2020) 1. doi: 10.1007/s13410-02000888-3. - 10. FISHER L, POLONSKY W, ASUNI A, JOLLY Y, HESSLER D, J Diabetes Complications, 34/12 (2020) 107748. doi: 10.1016/j.jdiacomp.2020.107748. — 11. GRABIA M, MARKIEWICZ-ŻUKOWSKA R, PUSCION-JAKUBIK A, BIELECKA J, NOWAKOWSKI P, GROMKOWSKA, KEPKA K, MIELCAREK K, SOCHA K, Nutrients, $12 / 10$ (2020) 3013. doi: 10.3390/nu12103013.

\section{B. Miškić}

General Hospital "Dr. Josip Benčević”" Slavonski Brod, Andrije Štampara 42, 35000 Slavonski Brod, Croatia e-mail: miskicblazenka@gmail.com 


\section{KONTROLA GLIKEMIJE U BOLESNIKA S DIJABETESOM TIPA 2 U UDOMITELJSKIM OBITELJIMA BRODSKO-POSAVSKE ŽUPANIJE TIJEKOM PANDEMIJE COVID-19}

\section{S A Ž E T A K}

U novonastaloj situaciji pandemije COVID-19 svakodnevni život pacijenata s kroničnim bolestima značajno se promijenio. Poznato je da pacijenti s dijabetesom tipa 2 imaju veći rizik od razvoja komplikacija bolesti COVID-19 i u novim uvjetima pacijentima je puno teže obavljati redovite dijabetološke kontrole. Veliki dio takvih bolesnika smješten je u udomiteljske obitelji koje se također prilagođavaju novonastaloj situaciji. Svrha ovog istraživanja bila je ispitati način i učestalost kontrole glikemije u bolesnika s dijabetesom tipa 2 koji su smješteni u udomiteljske obitelji u Brodsko-posavskoj županiji. Studija je provedena na način da smo uspostavili kontakt s pacijentima koji boluju od dijabetesa tipa 2 koji se nalaze u udomiteljskim obiteljima i njihovim skrbnicima. Mjerenje glikemije provodilo se nekoliko puta dnevno redovitim bilješkama, a podaci su nadopunjeni uvidom u medicinsku dokumentaciju pacijenata u bolničkom informacijskom sustavu. Studija je obuhvatila 33 bolesnika s dijabetesom tipa 2. Povezanost HbA1C s glikemijom natašte i posprandijalnom glikemijom bila je linearna. Nije bilo statistički značajnih razlika u regulaciji HbA1C prema vrsti terapije. Postojala je značajna razlika u broju komplikacija prema razini HbA1C (Hi kvadrat test $=25.982$, p <.001). Broj komplikacija općenito se povećavao jer je regulacija HbA1C bila lošija. U trenutnim uvjetima briga o pacijentima s dijabetesom tipa 2 značajno je ograničena. Bolji uvjeti za pacijente mogu se postići uspostavljanjem suradnje i svakodnevne komunikacije između njegovatelja, obiteljskih liječnika i, ako je potrebno, dijabetologa, posebno korištenjem mrežnih platformi i telefonske komunikacije, a sve u cilju ranog otkrivanja komplikacija dijabetesa i adekvatnog liječenja pacijenata u trenutnim uvjetima. 